\title{
REVISITING SECULARISM IN WESTERN CHRISTENDOM: A THEOLOGICAL AND SOCIOLOGICAL APPROACH
}

Dol: https://doi.org/10.33550/sd.v7i1.125

\author{
Kevin Nobel Kurniawan \\ Universitas Indonesia \\ Sekolah Kristen Calvin
}

\begin{abstract}
ABSTRAK: Artikel ini ditujukan untuk meninjau kembali proses sekulerisme dalam institusi agama Kristen di Barat melalui perspektif teologis dan sosiologis secara teoretis. Tesis utama dalam studi ini adalah pandangan sosiologis belum cukup memadai untuk menjelaskan menurunnya partisipasi masyarakat dalam kehidupan beragama. Oleh karena itu, dibutuhkan sebuah pendekatan teologis untuk menjelaskan bagaimana proses sekulerisme dalam memengaruhi kehidupan sosial dan gereja. Melalui argumentasi seperti ini, proses sekulerisme dapat dilihat dari beberapa tahap: Proses objektivasi agama Kristen dan proses kapitalisme dalam konteks industrialisasi Eropa, terpisahnya pengalaman personal individu dengan makna iman, dan proses individualisasi dan konsumerisme yang mendekonstruksi institusi agama dalam memasuki modernitas baru atau Postmodernisme. Artikel ini memposisikan argumentasi teologis Kierkegaard mengenai Kristendom sebagai pusat analisis untuk menjelaskan proses sekulerisme dalam konteks modernitas lama dan modernitas baru. Adapun begitu, studi ini juga mencoba untuk mengaitkan temuan di Eropa Barat dengan konteks kehidupan bergereja di Indonesia sebagai bentuk antisipasi terhadap perubahan sosial di tengah sekulerisme dan postmodernisme.
\end{abstract}

KATA-KATA KUNCI: sekulerisme, christendom, Kierkegaard, modernitas, modernitas cair, komunitas. 
ABSTRACT: The objective of this article is to revisit the process of secularization in the decline of Christian religion in the West through a theological and societal discussion on a theoretical level. By arguing a societal perspective alone is insufficient to provides a specific explanation to religious decline, a theological perspective would provides a prior explanation to further clarify how the process of secularization operates in relation to the internal dynamic of the Christian religion. The expositions of such arguments would argue that the process of secularization can be differentiates into several parts: The objectivation of Christian beliefs for capitalism in European industrialization, the de-attachment of individual to spiritual faith, and the process of individualization and consumerism that deconstructs religion in postmodernity. This article will posit the theological Kierkegaardian view of Christendom in dialogue with sociological arguments on modernity and postmodernity, and also to relate such findings into the Indonesian context to provides conceptual anticipation for postmodern social changes. KEYWORDS: secularism, christendom, Kierkegaard, modernity, liquid modernity, community.

\section{Introduction: On the Meaning of Secularism}

The study on secularism is a sociological and a theological work. The process of secularism, as proposed by different social thinkers, revolves around the issue of the disintegration of religious institutions. In this paper, secularism is understood not as a social phenomenon of religious institutions, but it is actually the disintegration of theological faith from within the church organization. By focusing in particular to the Christian religion, this study attempts to explore the relation between the theological and sociological analysis of secularism. There are several ideas which revolve on the meaning of secularism. First, it is considered as an intellectual movement. Second, it is a political intervention. Lastly, it is a change of individual lifestyle which attacks the idea of religious community.

The idea that secularism is an intellectual movement shows that it is an ideological power that attempts to replace religion in a society, one might understand this as "the spirit of secularism"1 Following the three stages of societal changes by Auguste Comte: society beings with theological myths will eventually transit towards a scientific and material account of reality regulated by secular ideology. Secularism presents an evolutionary

1. Peter Berger, "Secular Theology and the Rejection of the Supernatural: Reflection on Recent Trends," Theological Studies 38, no. 1 (1977): 39-56. 
approach of the world that a progressive society is a less religious one, and a religious society is a backward society. In this context, secularism is a totalizing ideology that is orchestrated to the process of "suppressing" religion.

Another view of secularism is understood as a political intervention in France: the separation of the religion and state. It begins as a form of critic towards pre-modern Catholic authority which previously blended the political and religious spheres to maintaining status quo. The prior form of such separation is found in the transition of the Protestant Reformation and the European Enlightment whereby both religious scholars and secular philosophers proposed the separation of the religious and political institution. Religious scholars, originating from the spirit of Protestantism such as John Locke, argues that "tolerance" is necessarily required to promote a civic life, and that the separation between the church and state is compulsory to maintain an orderly government and providing room for religious practices by individuals. ${ }^{2}$ In this context, the separation of religious and political is to open up a secular space whereby the preservation of religion, free thought, individual autonomy, and intercultural dialogue is kept free from political interventions.

However, there is yet another form of secularism which one would find most compelling to explain the fall of religion in the West. It focused the meaning of individualization, the change of lifestyle from a communal to an individualistic one, which is the main cause of religious decline in the Euro-Western hemisphere. If religious institutions promote a committed and communal form of living, and individualized lifestyle promotes an "anti-communal" one, then the process of individualization is also the process of countering religious institutions. One who is less religious is less dependent to an established religious institution. This article will focus on this view of secularism

What made this form of secularism so significant in the decline of Western Europe? Let us have an overview of the three scenarios of secularism: If it is an intellectual attack against religion (ideological), one would still find various Christians intellectuals promoting the progress of modernity and science - religion promotes science and intellectual life, science did not replace religion (Newton, Leibniz, Pascal, etc). If it is a separation of political from religious to promote secularism such as in France, one still would be able to observe the protection of religious life from the state based on such separation (the American secularism). Changes in social-political institution does not necessarily eliminate religion. However, in this article,

2. John Locke, A Letter Concerning Toleration (Indiana: Liberty Fund Inc, 2010), 53. 
it is proposed that the change of lifestyle is the root of secularism: that the stronger the process of individualization, the stronger the secular life. In this third form of secularism, we should understand this idea as a separation of the individual from the meaning of faith and communal life. The loss of faith begins in modernity and ends in religious legalism, the loss of communal life begins in postmodernity and ends in individualized secular life.

\section{Thesis Statement and Method}

The objective of this study is to describe the process of secularism through a theoretical approach. Therefore, the question which is attempted to be described in this article: "How do we understand the process of secularism in Western Europe within the scope of theological and sociological description?" In order to answer this question, the method which is applied to discuss the topic is conceptual hermeunitics through analysis of varying theoretical resources. By introducing introduce relevant thinkers to bring forward the discussion about faith, religion and secularism, the author would like to present Kierkegaard's philosophical thought as a theological standpoint to analyze both religion and secularism, Weber's thought on Protestantism, capitalism and modernity, and finally to present Bauman's thought on the current form of postmodernity and its deconstructive properties against religious institutions.

A theological explanation to describe the "process of religious disattachment" (having a religion but without faith) would serve as the basic framework to analyze the societal decline of Christian religion. Then, the author would like to differentiate the idea of Christianity from Christendom: Christianity is the theological faith and communion between the individual and God, Christendom is the sociological institution of Christian religion. If the Christian church has lost its gospel message, it would only fall into the shell of Christendom, and loses its capacity to provide theological and existential messageof the gospel. Then, the author would like to present how the church adapt to the socio-ecosystem, whether it is the Solid Modern society or the Liquid Postmodern society. In order to further clarify the structure of arguments, the author would like to propose the following diagram to elaborate the notion in this article: 


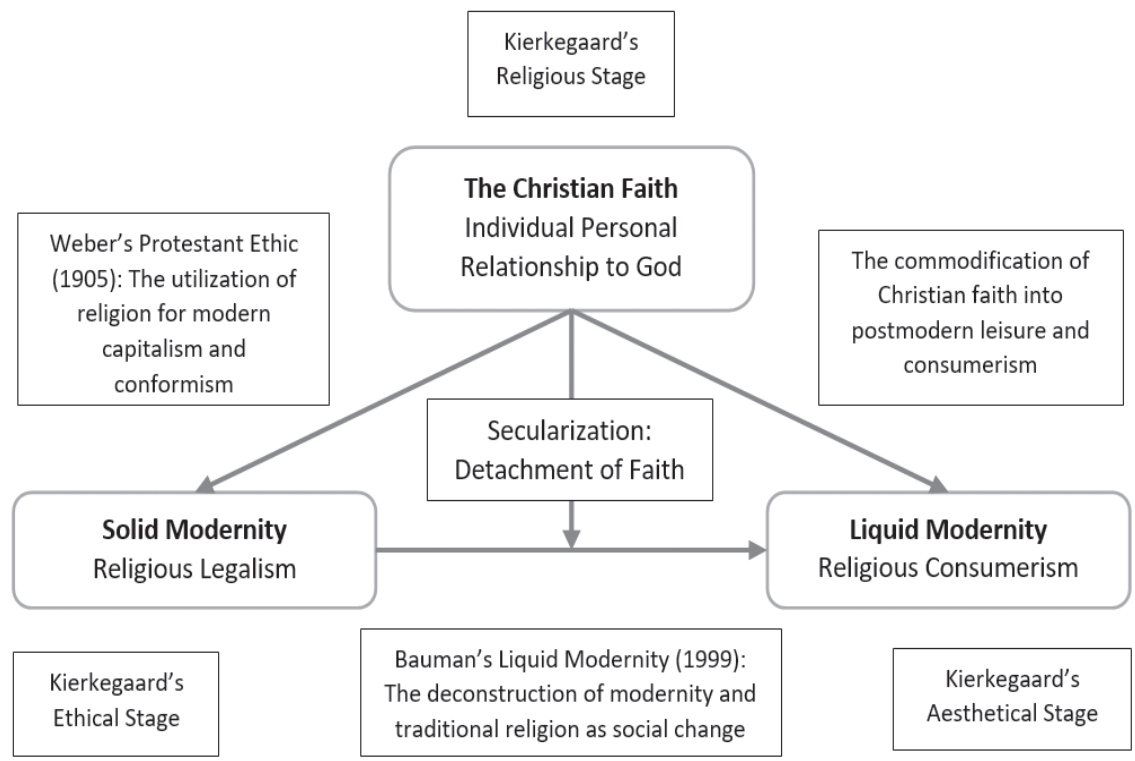

Figure 1. Sociological Analysis on Christian Religion in the Modern and Postmodern Context

\section{Objections on Christendom: A Theological Approach}

We shall begin by differentiating the theological and sociological view on secularism. On a theological dimension, religious secularism is about the individual's detachment to God, as described in the Kierkegaardian sense, that is the individual does not have communion with God. The ethical and "church-going" individual may not always be someone who strives for a faithful relation to God. On a sociological dimension, the definition of social secularism does not have the same depth as a theological one: it is only about the individual's detachment to the institution of organized church, and not about the individual attachment to authentic faith. A devout "church-goer" is sociologically considered "religious" but may be theologically unfaithful to God. Based on these assumptions, we can understand that there is two layers of secularism: first is the individual's loss of relation to God, and second is the individual loss of relation to the church.

The differentiation of theological and societal view of religion is further described more explicitly in the concepts of Christianity and Christendom. It is most clearly described by Kierkegaard in his book: "In "Christendom" the situation is a different one. What we have before us is not Christianity but a prodigious illusion, and the people are not pagans but live in the blissful conceit that they are Christians"3 In this phrase, Kierkegaard argued that the problem

3. Soren Kierkegaard,Attack Upon Christendom (New Jersey: Princeton University Press, 1968), 97. 
of Christianity is not found primarily in the non-Christians to who are consciously opposing against the Christian faith. However, the main problem is found within the body of the church whereby individuals confuse conformity to religiosity and obedience to the Christian faith, that one may appear ritually religious within its all ethical standards and yet without realizing that it is only a form of legalism.

Faith, according to Kierkegaard, cannot be substituted by an outward look of religious diligence. The faith of the individual cannot be substituted by an objectified form of Christendom, a genuine Christian transcends the boundaries of institutionalized religion and it must remain a personal communion to God. His critic is mainly directed to nominal Christians who participates in ritual practices during the $19^{\text {th }}$ century when modern capitalism is at its peak in the Danish golden age, one would be able to imagine the official Lutheran church in Denmark was attended by many Christian adherent, but only to find that they are just church attendees, and not faithful follower of Christ. By doing so, Kierkegaard saw "Christians" substituting Christianity with Christendom.

It is based on this concern that Kierkegaard pushes the argument further that individual faith is an opposition towards Christendom, that is nominal Christianity. Kierkegaard emphasized repeatedly the individual attachment to God is a crucial element of Christianity to defend against cultural Christianity that was once a conformist "lifestyle" in modern Denmark. "The person existing who chooses to pursue the objective path now enters upon that whole approximating deliberation that aims at bringing God to light objectively, which is in all eternity impossible since God is subject and therefore for subjectivity in inwardness" ${ }^{4}$ Faith, in other not to be secular, should remain a personal relation to God and that goes beyond the scope of cognitive knowledge and diligent rituals, according to Kierkegaard.

In this sense, the antonym of Christianity is not the opposing secular forces which surrounds the church from the external outside, whether it is the political or ideological movement which operates outside the circle of Christian religion. However, it is to the process of de-attachment to faith that is being practiced and propagated from within the Christendom itself. For Kierkegaard, once the church loses its Christian spirit, its character will be reduced into just an institutionalized religion: an objectified Christendom that works into conformity of world but not towards the sacredness of faith. In other words, Kierkegaard wanted to argue that secularism begins from

4. Soren Kierkegaard,Concluding Unscientific Postscript (Cambridge: Cambridge University Press, 2009), 168. 
within the church due to the process of becoming more assimilated and aligned to modernity.

Kierkegaard opposed the notion of modernity which reduced spiritual transcendence into a system of religious morality. Kierkegaard was anxious that spiritual faith, the attachment to the divine, were no longer internalized to the individuals as the priority of the church, and all that remains were normative moral legalism that converts the personal individual faith to God (subjective) into an impersonal form of societal-religious tradition (objective/objectified). By taking such notion into consideration, we could recognize that the Kierkegaardian argument against Christendom serves as a preliminary critic on Western secularism in early modern period. While Kierkegaard did not predict a drastic decline in the Christian religion in the postmodern era, but his arguments have already provided some insight of how Christian religion will fall later on: it has already diminished since in the beginning of modern period, the postmodern decline is only the logical consequence of the loss of faith.

Peter Berger would argue that the institutionalization of objectified Christian religion may not follow with the internalization of its spiritual message. ${ }^{5}$ If one would recall that secularism as an ideological and political intervention within the public sphere, which is the restriction and separation of religious institutions from other societal spheres, they do not have the same weight within the scope theological dimension; it is only a social phenomenon. It is after all the individual de-attachment from God, the subjective secularization, that becomes the stronger ideological and cultural movement in Euro-Western society. This movement has the capacity to ripple into the deeper layer of existential experience, prohibiting the individual from attending the theological meaning of Christianity. This subjective secularization is first conditioned by Christendom (modernity before 1960's) and later deconstructed by Postmodern ideologies (postmodernity after 1960's). The modern period remarks the instrumentalization of religious beliefs to promote capitalism and modernity, the postmodern period remarks leisure capitalism and the process of individualization which deconstructs the previous forms of modern institutions and religious meaning.

\section{Sociological Positioning of Religion and Modernity}

In order to further describe the relationship between Christian religion and secularism, it is essential to understand the relationship between religion

5. Titus Hjelm, "Peter L. Berger and the Sociology of Religion," Journal of Classical Sociology 18, 3 (2018): 231-248. 
and Euro-Western modernity. By relying on the Weberian perspective, modernity is defined as the "age of rationalism" whereby social actions and beliefs are measured within the idea of utility, instrumentality and rationalism. Thus, the secular view of modern society tends to regard the Christianity as premodern and irrational religion. ${ }^{6}$ While religious belief serves little function in practical application, capitalism and bureaucracy becomes the more relevant modern tool to promote progressivism and man-made endeavor. ${ }^{7}$ Weber describes that in the modern society, legalistic conformism is required to ensure the predictable process of societal progression. Without religion, modern society can continue with its progression by depending on human rationality: "In the case of legal authority, obedience is owed to the legally established impersonal order"8

And while modern perspective tends to hold a rather pessimistic view on religion, in Weber's analysis, he somewhat demonstrates certain degree of optimism by proposing that religious ideas, especially Protestant Calvinism, can support modern capitalism. There are two forms of utility that religious beliefs are useful to modern capitalism: psychological and economic. As modern institutions are moving towards the process of "over-rationalization" that Weber worries as the "iron cage" of impersonal modern bureaucracy will take over human lives. On this fundamental aspect of modernity, Weber attempts to provide an optimistic voice that religion might still provide assistance to minimize impersonal brute force of modern bureaucracy. Religious idea allows space of non-material explanations to provide psychological ease in modernity. It acts as the cultural mechanism to maintain individual psychological well-being. ${ }^{9}$

On the other hand, religion serves the economy. According to Weber, Protestantism (particularly Puritanism and Calvinism) has served as the primary ideological force to the emergence of modern capitalism. As religion urges the individual to participate in ascetical works to labor hard and reinvest new savings, modern capitalism is able to operate well. Weber saw that it is Christianity, Protestant-Calvinism, in particular which support the growth of Western economy: "Without doubt Christian asceticism, both outwardly and in its inner meaning, contains many different things. But it has had

6. Anthony Giddens, The Consequences of Modernity (Cambridge: Polity Press, 1990), 116.

7. James Coleman, "The Rational Reconstruction of Society: 1992 Presidential Address," American Sociological Association 58, no. 1 (2018): 1-15.

8. Max Weber,Economy and Society: An Outline of Interpreting Sociology (California: University of California Press, 1978), 215.

9. Peter Berger,Questions of Faith: A Skeptical Affirmation of Christianity (Oxford: Blackwell Publishing, 2004), 31. 
a definitely rational character ${ }^{10}$." Based on this statement, Weber argues that the Christian religion was able to fit and even direct the logic of modernity; Christianity is not irrational and premodern, but it is a significant religious rationale to support modernity, capitalism and the progression of Western Europe. He has further argued that since capitalism prohibits idleness, the Calvinistic principle of election is psychologically compelling to prevent such act, as he quotes Calvin's work: "Waste of time is thus the first and in principle the deadliest of sins. The span of human life is infinitely short and precious to make sure of one's own election ${ }^{11 "}$

Based on Weber's arguments, promoting religion as a cultural utility would be a rational means to stabilize and forward the process of modern capitalism. In the societal perspective, the Christian religion has not been diminished by modern secularization. Instead, it has been joined into modernity; the Christian religion is "modernized". The church is not "left out" as a pre-modern social institution, but have been embedded, formulated, and "reformed" into modern system which directs the Western society. The Weberian view on religion is quite optimistic towards the ecosystem of modernity, giving religion a chance to provide a "sociological contribution" to the society. However, it is also within this premise that shows the loss of "sacred character" in the Christian religion.

In the modern society, religion is being used to create conformity to "worship" the impersonal idol of modern capitalism. By converting religious doctrine for economic purposes, this act has the tendency to reduce faith into religious legalism and cultural conformity to the machine of modernity. Kierkegaard would argue that Christianity has been modernized into Christendom, that Weber has also participated into the "theological crime" of objectifying Christianity into instrumental capitalistic ideology. The process of secularization begins from within the church. In other words, Weber's Protestant Ethic follows the idea that religion may act as positive resource and utility to fuel the motors of capitalism, it is not false that religion contributes to modern society. Nonetheless, the same form of argument can be interpreted in another way: religion is only a means to an end, that once religion has completed its utility of initiating capitalism, modernity no longer needs to rely on religion, and can continue to operate independently and utilize other pragmatic means to satisfy the logic of modern capitalism. This is the unintended consequence of Weber's Protestant Ethic; it will eventually end up into "Modernity without Protestant ethic". 


\section{Postmodernism: The Decline of Christendom in Western Europe}

The participation in Christian religion does not diminish effectively during the industrialization of Europe, so what explains the fall of Christianity? This article argues that modernity has weakened the Christian religion into a capitalistic form of religious legalism. However, it is the next step of Postmodern social changes that will deconstruct both religion and modernity. It is the individualizing forces promoted by Postmodernism that actively attacked religious institutions.

By referring to Callum Brown's book (2001), The Death of Christian Britain, it is discovered that the Christian religion still retains its cultural element in the society till $1950^{\prime} \mathrm{s}^{12}{ }^{12}$ That without the state having put individuals into sanction, people still voluntarily attended church services. Heyck (2018) presents familiar argument that although religion experience a slight decline before the World War due to the process of urbanization, and yet religion still retained cultural influence in the modern society. ${ }^{13}$ Based on several statistical findings such as these, it is observed that modernity, the discourse of "science \& technology", and industrialisation may not be the determining factor of secularization in the societal sense. ${ }^{14}$

However, it is only during the 1960's (after the World War), affiliation towards religious practice and attendance fall very rapidly. Several statistics have shown that religious attendance is continuing its decline as new generation replaces the older generation in Britain. The statistical findings agree that a "secularizing force" happened in between 1960 and 1970 as Brown argued that there is a growth of a new narrative which deconstructs the discourse of the Christian and modern narratives in the Euro-Western hemisphere. It is a postmodern ideology which is symbolised by youth social movement, sexual revolution, and anti-modern ideologies which counters particularly the previous norms of modern society. The weakening of social commitment and social structures, especially towards the church and family where the idea of "sacredness of communal life" is made no longer relevant - this becomes the prime factor of secularization:

12. Callum Brown,Death of Christian Britain: Understanding Secularisation 1800-2000 (London: Routledge, 2001), 223.

13. Thomas William Heyck, "The Decline of Christianity in Twentieth-Century Britain," North American Conference on British Studies 28, no. 3 (2018): 437-453.

14. Callum Brown. "What Was the Religious Crisis of the 1960s?" Journal of Religious History 34, no.4 (2010): 468-479. 


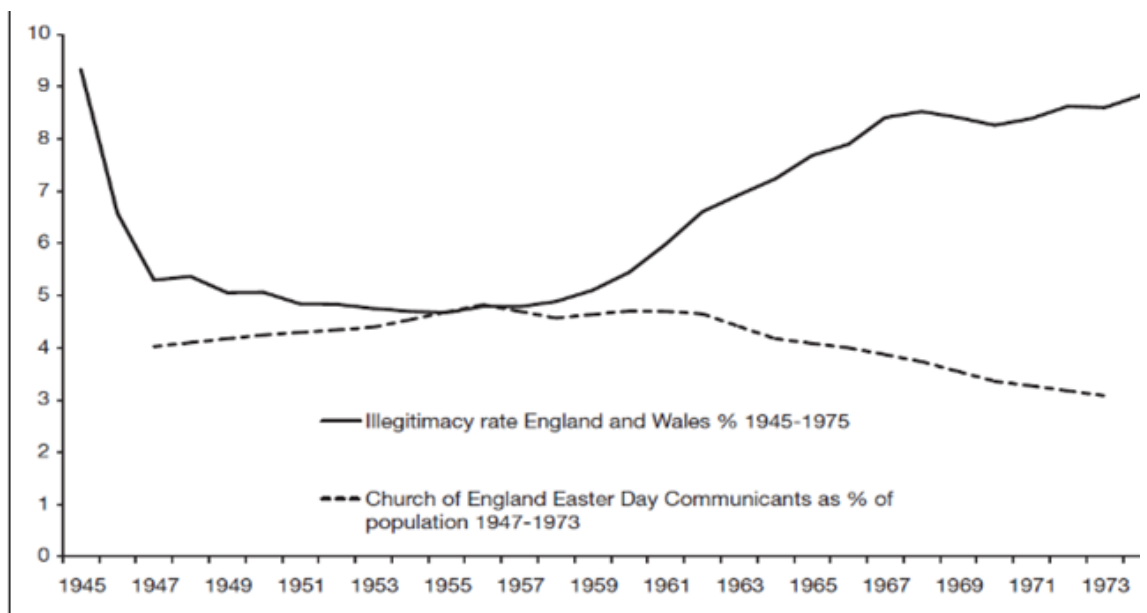

Figure 2. Callum Brown. Death of Christian Britain: Understanding Secularisation 18002000, 2001, Routledge, London, 223.

The graph above shows the escalation of individualistic lifestyle. Illegitimacy rate represents the amount of child born outside religious marriage. The increase of illegitimacy among the Baby Boomers is parallel to the decrease of church participants. This is due to the fact that the idea of postmodern culture, which attacks communal commitment is very dominant, especially to family and religious institutions - for it is religious institutions that promote the exclusivity of marriage. The pattern of individualism and economic consumerism is being applied the same way into human relationship: the idea of commitment and sacred promise between individuals within the form of community has become an offensive culture in the progress of Western secularization and individualization.

After 1960's, Postmodernism is the ideological movement that criticizes the solid structure of modernity. Postmodernism liberalized the existing institutional and attacked modernity's normative structure of obedience, including the communal bond within the Christian religion. In this period, the traditional Christian religion was unable to adapt with the postmodern process which challenges its religious ascetical norms. Capitalism has also taken its new form of "leisure capitalism" which denies the previous form of productive capitalism. The promotion of individualized lifestyle is not compactible with the previous forms of narratives, whether it is modern or communal. It deconstructs modern form of productive capitalism and the communal commitment of religious communities and family. Thus, making any form of organized social institution irrelevant, including the existence of traditional religion. 
By borrowing on Bauman's metaphoric term of solid and liquid modernity, it is suggestable that the process of secularism can be further be extended into Christendom, that the metaphors are also applicable to "Solid-Liquid" typology of the church: Modern and Postmodern Christendom. Mainline Christianity have a more "solid" and formulaic forms of confessional beliefs and hierarchical church organizations while contemporary Christian denomination is less hierarchical and does not have a set of doctrinal structure. The decline of Christendom is due to the Postmodern transition from a "fixed" cultural norm of Christian beliefs into a "liquid", sporadic, and consumptive form of religious and economic lives.

Some churches adopt the new spirit of consumerism and individualistic Postmodern worship method or else it will eventually fall in decline just like any modern social institutions. As solid modern social structures are reaching its conclusion, postmodernity arrived in the Western hemisphere. Bauman has described postmodern way of living, or rather known as "Liquid Modernity", a condition whereby the solid structure of modernity which promotes obedience, conformism and predictable social actions have been undermined: "If orthodox sociology, born and developed under the aegis of solid modernity, was preoccupied with the conditions of human obedience and conformity, the prime concern of sociology made to the measure of liquid modernity needs to be the promotion of autonomy and freedom"15

Various sociologists and commentators on postmodernity have mostly agreed that the postmodern period is comprised of a radical different ideological and institutional characteristic which were not found in the previous form of modern and premodern times. The society is now turning to towards of "service-based" economy, a new form of individualized lifestyle and radical discursive critic to the previous form of modernities. Although these sociologists have not provided a clear description of religion in their analysis of social change, their observations have hinted that the increasingly individualized Western lifestyle has become the primary explanation (prima causa) on the decline of traditional Christianity in the West.

\section{Findings}

The utility of religion is replaced by the new form of consumerism. It operates on the basis on individualism. ${ }^{16}$ On Kierkegaard's philosophical terms, the aesthetic individual becomes the protagonist of the postmodern

15. Zygmunt Bauman,Liquid Modernity (Cambridge: Polity Press, 2000), 213.

16. Zygmunt Bauman,Liquid Love (Cambridge: Polity Press, 2003), 45. 
economy and sexuality, to which religious become the new antagonist. This means, the postmodern individual views any form of social institutions which binds and restricts their movement for desire as "the enemy". And especially for traditional mainline Christianity, which argues for self-denial, ascetical work, and social commitment - this is considered an "irrational" and "non-consumptive" religion in the postmodern times.

For religion implies the notion of sacrificial social commitment, but the process of individualization has argued that organized "Modern Christendom" is not suitable, or rather, offensive for the "Liquid Modern Individual" who moved to defy any forms of communal and organizational commitment. The postmodern movement against the structural constrains of social institutions and cultures do not only stop at a societal level, but it has had penetrated even into the psychological and spiritual layer of the human being. To commit to faith is to be loyal to certain set of religious structure and commitment. It is this factor that make the third form of secularism, the change of lifestyle, as more dynamic and dramatic as compared to the intellectual and political ones. ${ }^{17}$

Currently, the decline of Christian religion does not necessarily eliminate all forms of supernatural belief. Instead, it has resulted with the rise of non-affiliated individuals as most of the European population regarded themselves as "non-practicing Christians" or "Nones" whereby they still hold to the Berger's argument that a supranatural cause, or "a belief in higher power" is still relevant. However, this also means that the individual may believe in "God" but commits to not be part of any religious institutions, community or organizations because this undermines the freedom of the individual. Or perhaps, these views show that it is the individual whom become the center to determine the belief they desired in a postmodern manner.

The Postmodern lifestyle demands radical uncommitted freedom. And thus, the current form of popular Christianity eventually moves towards a "Postmodern Christendom" where the individual is made free to not have any fixed membership of any religious institution. This gives the individual at the center of social life, making new possibilities of "connecting and disconnecting" to any religious institutions and community at any given time. The emerging church, contemporary forms of churches, non-mainline denominational or non-denominational churches, where individuals are kept as "attendees", and not communities, are the most common form of 188.

17. Zygmunt Bauman,Postmodernity and Its Discontents (New York: New York University Press, 1997), 
Christendom in the Postmodern era.

This resonates to Kierkegaardian theological argument about religion. When the individual is detached from spiritual faith, then the consequence would result in the decline of Christianity. The meaning of decline may not always be an apparent "loss of adherents" from a sociological view. People still go to church, even if it is a contemporary one. However, it may mean a transition from one form of Christendom to the next, from the Modern into Postmodern Christendom, the ethical into the aesthetic stage. Unlike traditional mainline churches, contemporary churches operate on the basis of a more flexible movement of attendance, networking, and operates on the logic of consumerism. Churches were modified to refit into the logic of Liquid Modernity whereby individual participation is guided by the pursuit of leisure and consumerism, and that religious institutions were also refabricated into such familiarity of "being artistic" to resonate the current social context.

Nonetheless, from a theological perspective, the Kierkegaardian argument would still criticize such form of religiosity as "secular" for it is still operating within the logic of Christendom while only attaining its new "liquid and postmodern properties". Thus, the contemporary church or "Postmodern Christendom" which spread within the consumer society is not an opposition towards "Modern Christendom", it is only an extension, a reconstructed form of traditional "Christendom" into malleable "Postmodern Christendom". As Weber argued, the logic whereby modern Christendom moves are according to the idea of productive capitalism. On the contrary, the logic whereby postmodern Christendom moves are according to the idea of religious commodification for consumers' leisure as described by Bauman. However, both forms of Christendom are worldly in accordance to capitalism, it is not Christianity which is joined into authentic faith.

While the societal perspective would demonstrate that religion has returned to its utility in the consumer society, Kierkegaard would still argue otherwise that it is still a "social utility"; the aesthetical individual is still bound to the logic of "Postmodern Christendom", and not to faith. Although the process of desecularization of Christian religion is still occurring in the Post-Christian society, it may not always point towards the individual attachment to the Divine. Thus, on practical terms, the discussion of secularism cannot be defined with just the practical indicator of "church attendance" alone. The societal indicator of secularism must be further clarified by the theological view of the individual's personal attachment to certain religious beliefs, the personal communion to the Gospel. 


\section{Discussions}

The societal perspective often omits the "internal theological attachment of the individual to spirituality", and mostly observes the phenomenon of "external societal secularizing forces" around the Christian religion. Thus, perhaps by employing this approach (theological and societal), it will allow us to comprehend that secularizing forces may not always be the result from the external societal forces towards religious institutions, but it also points towards the internal dynamic of Christian institutions. Religious institutions are always in dialogue to societal context from within: its role in attaching the individual to the transcendence, and also its response towards external the societal institutions. The decline of Christian religion may not necessarily be directed to the external structure institutions, but it is within the subjective conscience of the individual in relation to the transcendental message of the gospel.

The gospel is transcendent and Christian religion is societal. While there is still an irreconcilable conceptual gap between the theological and sociological view of secularism, both views should not be separated but continually put into reflexive dialogue. Kierkegaard retains the notion that spiritual faith is not a societal phenomenon, but his view has a theological and societal implication. True faith will have an impact to the secular life of economy and culture; however, economic and cultural life alone may not always reflect faith. By introducing the theological perspective, the dichotomy between "Christianity-Christendom" is further clarified. The point that the growth or decline of Christian religion (Christendom) is dependent to the loss of transcendence when religious institutions is assimilated world. When the church no longer maintains its Christian spirit, it will have to take the external shell of "Modern-Postmodern Christendom(s)" to adapt to the society, but it is only reflecting having no internal core of the gospel message.

\section{Implication for Indonesia's Christian Church}

The study of secularized West is interesting as it provides lessons about the rise and fall of the church. The secularized and secularizing West is shown by the Western Europe and American society. The former is already within its state of Post-Christendom, and the latter is in the process of transition into dense secularism. In this article, the author would like to suggest that the Indonesian society, particularly the church, follows more into the American model. The typological character of separation between the church and state appears to be similar with the American society. On the other hand, we have less the character of European Enlightment as intellectual life is not replacing the religious life of the Indonesian society. And yet, both modern 
and postmodern energies are present; both traditional and contemporary churches are operating simultaneously.

First, let us locate the Indonesian Christian church in comparison to the American context. In Indonesia, Christianity is not the majority religion. As a minority religion, one would expect that there is a higher intensity of subjective consciousness "of being a Christian" within a non-Christian population as its majority. However, becoming a minority does not necessary provide a "safer ground" that the Christian faith would not deteriorate into Christendom. Spirituality, that is the gospel message, remains central within the internalization of the Christian message. Faith remains a substance of religion to which the individual relates to The Divine Other (God); faith is not determined by a statistical number to whom one belongs to a religious group, whether it is majority or minority.

Second, Indonesia's plural Christianity is also found in various forms of modernities. Unlike the Western context, Indonesia does not have a strict transition from modernity to postmodernity, but once again, having simultaneous ideologies operating within its society: a mixture of premodern, modern, or postmodern. In the urban context, the Christian religion would fall into a "Postmodern Christendom" whereby Christian practices would follow "new trends" and consumptive lifestyle. In other contexts, "Modern Christendom" which promotes religious conformism and rituals is practiced bureaucratically. In the more rural context, the Christian religion perhaps would neither fall into a "Modern and Postmodern", but it will fall into its pre-modern culture of mixing Christian practices and local ethnic traditions. The combination of religion and local tradition points to show that the Christian faith is still susceptible into mere societal norms, and vulnerable to lose its substance - it is a traditional norm that puts Christian religion as an additional ritual and symbolism, and yet having less the substance of faith.

Based on these considerations, we can observe the study of Western secularization and find its relevance into the Indonesian context. On the theological dimension, one might all agree that the Christian faith is the fundamental substance within the Christian religion. To lose faith in the Gospel is to lose Christianity despite having repetitions of religious rituals in Christendom, whether it is Pre-modern, Modern, nor Postmodern. On the societal dimension, the Western history has shown that the effect of postmodern ideologies, consumptive economic lifestyle, and sexual liberation which centers the individual as the primary actor in the society is the key element to secularization. The deconstruction of individual commitment to communal, social, and religious lives have become the driving force to the fall of Christian religion, and these has been increasingly become more 
evident among the younger generations, also known as "The Millenials"18

By putting these various factors into place, we are able to recognize that on the layer of societal observation, the Christian religion, as a pre-modern (tribal) or modern (solid) form of Christendom, may experience a drastic decline of religious participation once it is unable to adapt into the postmodern context. The impersonal form of religiosity in Indonesian Christendom may eventually serve as a fertile soil for Postmodern ideology which will deconstruct the church. Thus, if one is to defend Christianity, one's reflexivity should point towards the direction of transcendence, and not only the adjustment of the church institutional features into the postmodern ecosystem. If the church responded correctly, Postmodernity could provide a fertile soil of possibility and plurality, to which the individual is challenged to continually dialogue with one's faith - to question and re-question one's particular beliefs, and thus deepening a theological reflection to the Christian faith.

It is to be noted that the postmodern ideologyis not only happening in the present, whereby religious and denominational plurality is increasing, but will continue to increase in intensity as to economic growth, globalization, and individualization in the future - that is the transformation of lifestyle into becoming more individualistic and less communal. And as lifestyle changes come into play, consumptive lifestyle will follow and deconstructs the basic structure of religion and conventional form of family structure. The author suspects that secularism and its postmodern features will thicken even more in the coming decades when economic growth and individualized lifestyle will flourish in 2030-2040's.

\section{Recommendation}

This article would like to suggest two basic solutions for Christian institutions in Indonesia. The first solution is theological. As the Christian faith is a transcendental spirit, Christian institutions should not neglect the importance of individual reflexivity in understanding the substance of the Christian message. To lose the substance, that is the Gospel message, is to lose Christianity. The room for the individual to reflect and accept one's faith is not and never to be substituted by conformism or legalism of Modern Christendom, or by the leisure consumerism of Postmodern Christendom. Perhaps, the participation in any form of legalistic or leisure in Christendom(s) is the result of the loss of faith in the Gospel.

18. Bilangan Research Center,Temuan Hasil Survei Spiritualitas Generasi Muda Kristen Indonesia (Jakarta: Bilangan Research Center, 2018), 18. 
The individual may participate in the impersonal objectified form of Christendom, it does not guarantee the personal internalization of Christian message. And thus, without personal faith, Christendom is no more than a social gathering or social club. The number of attendees may be increase, but it is only a crowd in Christendom, and may not be the faithful follower of Christianity. Hence, it is through this reduction of Christian life that one would either fall into religious legalism or liberalism to compensate the loss of faith - metaphors of "Elder Brother and Younger Brother" is familiar to the structure of Modern and Postmodern Christendom(s), both "brothers" (modernity) having becoming religious or secular, but both lost the spiritual communion with God. ${ }^{19}$

The second solution would be upbuilding a communal relation. ${ }^{20}$ If Christian institutions would like to build an "I and Eternal Thou Relation", one should not neglect "I and Thou Relation" for any theological meaning to be accepted by faith, it is to be followed by the practice of Christian community. Faith, the "I and Eternal Thou" relation, is to be practiced through community of "I and Thou" ${ }^{21}$. The societal Christendom is operated on the basis of social attributes: a modern society produces a mechanistic-bureaucratic religion; a postmodern society produces a consumptive-leisure religion, to which neither both forms nor the mixture of both Christendoms are capable to reach the transcendental core of Christian gospel. Community symbolizes the notion of transcendence among human relations, that within the current of societal ecosystem, the notion of intimacy and "pure" social relation remains important for its participants in the midst of individualized and secular society. ${ }^{22}$

On more concrete terms, the practice of spiritual retreats, regular small group meetings, and group prayer - taking moments away from the mundane secular activities and gather within the sacred space to which individual can re-access the message of transcendence and communality is crucial to relive the Christian Gospel. Thus, among these communal meetings, individual could escape the modern and postmodern spheres of life, and "retreat away" from the secular iron cage of Christendom into the religious chamber of faith. It is through these relational participation among Christian adherents could maintain and live their Christian life

19. Timothy Keller,The Prodigal God: Recovering the Heart of Christian Faith (New York: Penguin Group, 2008), 70 .

20. Martin Buber,Between Man and Man (London: Routledge \& Kegan Paul Ltd, 1994), 60.

21. Amitai Etzioni,The New Golden Rule: Community and Morality in a Democratic Society New York (Basic Books, 1996), 187.

22. Martin Buber,I and Thou (Edinburg: T.\&T. Clark, 1986), 34. 
within the Premodern, Modern and Postmodern societal condition. This is not to say that Christian religious community should completely maintain its "Relational Form" and refrain every form of societal forces. However, the discipline of community in maintaining its relational substance is derivative of the theological meaning, it is a definitive element to anticipate and confront secularizing forces from within and outside of Christian institution.

\section{Acknowledgement}

The author is grateful for Professor Jon Stewart's willingness to provide online lectures on Kierkegaard and generous time to comment comprehensively for the article's initial draft. And the author would like to provide his gratitude to Francisia Ery Seda, Ph.D for her long dedication in teaching and advises in the field of Sociology and Philosophy. Lastly, the author is indebted to Ivan Kristiono, M.Hum. M.Div for his lessons on Kierkegaard in my early years of philosophical study. 
